\title{
CHANGES IN NURSING STUDENTS' ATTITUDES TOWARDS NURSING DURING UNDERGRADUATE STUDY
}

\author{
Snježana Čukljek ${ }^{1}$, Vesna Jureša ${ }^{2}$, Cecilija Grgas Bile ${ }^{3}$ and Biserka Režek ${ }^{3}$ \\ ${ }^{1}$ University of Applied Health Sciences, Department of Nursing; \\ ${ }^{2}$ School of Medicine, University of Zagreb; ${ }^{3}$ Sestre milosrdnice University Hospital Center, Zagreb, Croatia
}

\begin{abstract}
SUMMARY - The aim of this study was to determine the attitudes of nursing students towards nursing, and changes in their attitudes during the study. A quantitative study with pre-post survey was conducted among nursing students enrolled in first study year in the academic year 2012/2013 $(\mathrm{N}=115)$ and third study year in the academic year 2014/2015 ( $N=106)$. Students voluntarily and anonymously completed a questionnaire consisting of demographic information and the Nursing Image Questionnaire, which includes 30 items that assess how an individual looks at the roles and tasks, values, social stereotypes of nursing, professionalism and performance of nurses. The results indicated that students had positive attitude towards nursing at the beginning and during the study. During the study, there was a positive change in attitudes in the majority of items of the questionnaire, whereas at the end of the study lower attitude was expressed in only four items. The study conducted among nursing students indicated that students' attitudes changed during the study, influenced by the acquisition of knowledge and skills. During the study, students acquire a more realistic perception of nursing, and adoption of professional values emerges.
\end{abstract}

Key words: Nursing, education; Baccalaureate study; Perceptions; Attitudes

\section{Introduction}

Nurses and health system face numerous challenges; on the one hand, there is the professionalization of nursing, expansion of nurses' powers, technology and computerization, and on the other hand, an insufficient number of nurses in the health system and increasing health care demands related to population aging, chronic diseases and malignancy. To ensure the provision of high quality nursing care, it is important to ensure quality education and mindful selection of applicants who enroll and choose the nursing profession as a vocation.

The number of candidates who enter nursing studies, which is traditionally a female occupation, has decreased since women have been offered a number of

Correspondence to: Snježana Čukljek, $R N, B s N, P h D$, University of Applied Health Sciences, Mlinarska 38, HR-10000 Zagreb, Croatia

E-mail: snjezana.cukljek@zvu.hr

Received May 23, 2015, accepted February 27, 2017 attractive professions that in the mid- $20^{\text {th }}$ century were considered male occupations, and new professions are still developing. Also, the number of places for nursing studies at higher education institutions has been limited. Therefore, it is extremely important to enroll people in this study who are willing not only to study nursing but who understand the needs of the others, and are empathetic, aware of their reactions to the others, critically reflect in the care conducted and are prepared for lifelong learning. The number of students who do not end up enrolled nursing studies ranged up to $30 \%^{1}$. The most common reasons for non-completion of the study are a failure during the study, personal and family reasons, wrong choice of career, unrealized expectations about the study, and nursing and financial difficulties ${ }^{2,3}$. It is expected that nurses during education acquire the necessary knowledge, skills and attitudes, i.e. competences for independent, responsible, safe, quality and professional conduct of nursing care.

Research shows that students enroll nursing for altruistic reasons such as desire to help and care for the 
sick $^{4-7}$, economic reasons such as security of work place $^{7,8}$, and their previous experience with nurses and health environment ${ }^{9,10}$. Significant for selection of occupation are role models in the family, among friends, as well as positive experiences with nurses ${ }^{7,9-12}$. Previous positive experience when caring for the sick, and insufficient knowledge of the nursing profession often cause idealistic perception of nursing, which can cause stress and discomfort during the study due to a conflict between the ideal image of nursing and nursing what it really is $s^{9,13,14}$.

The aim of this study was to determine the attitudes of nursing students towards nursing, and changes in their attitudes during the study.

\section{Subjects and Methods}

\section{Study design}

A quantitative study with pre-post survey was conducted. Students completed a questionnaire in the first year of study (2012) at the first lecture related to the field of nursing, before the class had begun. The second part of the research was carried out during the last semester in 2015, at one of the last lectures during the study.

\section{Examinees}

The study was conducted among students of fulltime study in 2012, including those having enrolled the first year of nursing study at the University of Applied Health Sciences in Zagreb. Of 123 students enrolled in the first year of the study, the questionnaire was completed by 115 (93\%) students. Most of the examinees were women $89.6 \%(\mathrm{~N}=103)$, age range $18-25$, mean age $\mathrm{M}=19.59$ ( $\mathrm{SD}=1.41$ ). Only six examinees had previous work experience as nurses.

The second survey performed at the end of the third year of the study included 106 students. A small number of students filled out the questionnaire due to cancellation of the study and irregular fulfillment of student obligations. The pattern was the same as the proportion of women at the beginning of survey (89.6\%). Age ranged from 21 to 28 , mean age $M=22.58$ $(\mathrm{SD}=1.45)$. Now again, only six examinees had previous work experience.

\section{Data collection and instrument}

Students voluntarily completed an anonymous questionnaire that included demographic information and Nursing Image Questionnaire (NIQ7) translated into Croatian. Students identified the following demographic information: age, gender, job title, years of service, and marital status. The Nursing Image Questionnaire has been developed by Toth et al. ${ }^{15}$, and includes 30 items that assess how an individual looks at the roles and tasks, values, social stereotypes, professionalism and performance of nurses. Examinees answer questions by rounding the Likert scale wherein the points in each item are in the range of 1 to 5 , depending on the degree of agreement with the statement on nurses and nursing, where 1 represents full disagreement and 5 full agreement. When scoring, it is necessary to transliterate 7 items $(4,9,15,17,19,23$ and 27), where the answer 1 is scored 5 points, 2 by 4 points, 4 by 2 points, and answer 5 by 1 point. On completing the questionnaire, the examinee can achieve at least 30 to a maximum of 150 points. A higher result achieved on the questionnaire indicates a more positive attitude towards nursing and lower result indicates negative attitude. Content validity was confirmed by experts ${ }^{15}$, who analyzed NIQ-7 twice to determine the representativeness and relevance of the items. The construct validity was determined by the method of group differences. In the study conducted by Toth et al., the reliability measured by Cronbach alpha coefficient ranged from 0.75 to $0.80^{15}$.

For the purposes of this study, after the authors' approval to use the questionnaire, in addition to translation into Croatian, a cross-cultural adaptation was conducted. On cultural adaptation, we were led by the recommendations issued by Beaton et al. ${ }^{16}$. When translating the questionnaire, it was necessary to do adaptation of items 4 and 26. In the original questionnaire, item 4 reads Nurses should wear the white uniform in order to be recognized; in accordance with the characteristics of nursing uniforms in Croatia, the item was modified, and after adaptation in the translation it reads: Nurses should wear blue uniform in order to be recognized. In order to make clear item 26 , the translation listed advanced levels of education and in the questionnaire the item reads: Nurses with completed undergraduate nursing studies and graduate studies significantly contribute to patient care. In this study, the reliability measured by Cronbach alpha coefficient was slightly lower than in the study by Toth et al. ${ }^{15}$, i.e. 0.67 to 0.70 . 


\section{Statistics}

Data were entered in the Excel spreadsheet and analyzed by use of SPSS 17.0 software for statistical analysis. Results were presented in tables showing descriptive statistics parameters. The KolmogorovSmirnov test was used to determine normality with reliability of $\mathrm{p}<0.05$. To test statistical significance of differences, students' answers in the first and third year of the study Mann-Whitney U test was used, with reliability of $\mathrm{p}<0.05$; the results are shown in Table 1 .

\section{Ethical criteria}

The Ethics Committee of the University of Applied Health Sciences approved the research (CLASS:
602-04/12-18/322, REGNO: 251-379-1-12-02, June $4,2012)$. Examinees were verbally explained the purpose of the research, they received a written notice for the examinee that outlines the purpose of research, and they signed the consent form to participate in the research. Student participation in the research was voluntary and anonymous.

\section{Results}

Descriptive statistics of the results for students in the first year $(\mathrm{N}=115)$ and third year of the study $(\mathrm{N}=106)$ is shown in Table 1. Arithmetic means ranged from $M=2.34$ to $M=4.5$ for first-year results and from

Table 1. Results of descriptive statistics and Mann-Whitney U test

\begin{tabular}{|c|c|c|c|c|c|c|c|c|c|c|}
\hline \multirow{2}{*}{ Item } & \multicolumn{4}{|c|}{ First year of study } & \multicolumn{4}{|c|}{ Third year of study } & \multicolumn{2}{|c|}{ Mann-Whitney U test } \\
\hline & Min & Max & $\mathrm{M}$ & SD & Min & Max & $\mathrm{M}$ & $\mathrm{SD}$ & Result & $\mathrm{p}$ \\
\hline 1. Nurses are patients' advocates. & 1 & 5 & 3.70 & 0.93 & 2 & 5 & 4.42 & 0.74 & 3323.500 & $<0.001^{* * *}$ \\
\hline $\begin{array}{l}\text { 2. Nurses protect patients in the health } \\
\text { care system. }\end{array}$ & 2 & 5 & 3.82 & 0.92 & 1 & 5 & 4.11 & 0.87 & 4977.500 & $0.017^{* *}$ \\
\hline $\begin{array}{l}\text { 3. Nurses participate in the development } \\
\text { of health care policies. }\end{array}$ & 1 & 5 & 3.52 & 1.02 & 1 & 5 & 3.78 & 1.02 & 4974.500 & 0.068 \\
\hline $\begin{array}{l}\text { 4. Nurses should not wear the blue } \\
\text { uniform in order to be identified.* }\end{array}$ & 1 & 5 & 2.34 & 1.09 & 1 & 5 & 2.57 & 1.26 & 5412.000 & 0.207 \\
\hline $\begin{array}{l}\text { 5. Nurses act as resource persons } \\
\text { for individuals with health problems. }\end{array}$ & 2 & 5 & 4.50 & 0.66 & 3 & 5 & 4.60 & 0.51 & 5715.500 & 0.354 \\
\hline $\begin{array}{l}\text { 6. Nurses in general are kind, } \\
\text { compassionate human beings. }\end{array}$ & 1 & 5 & 3.51 & 0.97 & 2 & 5 & 3.76 & 0.86 & 5189.500 & $0.043^{* *}$ \\
\hline 7. It takes intelligence to be a nurse. & 1 & 5 & 3.72 & 0.94 & 2 & 5 & 4.09 & 0.81 & 4793.000 & $0.003^{* *}$ \\
\hline $\begin{array}{l}\text { 8. The service given by nurses is as } \\
\text { important as that given by physicians. }\end{array}$ & 1 & 5 & 4.40 & 0.86 & 3 & 5 & 4.74 & 0.54 & 4712.000 & $<0.001^{* *}$ \\
\hline $\begin{array}{l}\text { 9. Everyone would not benefit if nurses } \\
\text { spent less time in school and more time } \\
\text { caring for patients.* }\end{array}$ & 1 & 5 & 3.06 & 0.98 & 1 & 5 & 3.19 & 1.24 & 5612.000 & 0.289 \\
\hline $\begin{array}{l}\text { 10. Nurses integrate health teaching } \\
\text { into their practice. }\end{array}$ & 1 & 5 & 4.26 & 0.65 & 2 & 5 & 4.47 & 0.59 & 5016.500 & $0.010^{* *}$ \\
\hline $\begin{array}{l}\text { 11. Research is vital to nursing } \\
\text { as a profession. }\end{array}$ & 1 & 5 & 3.85 & 0.89 & 2 & 5 & 4.41 & 0.73 & 3904.500 & $<0.001^{* *}$ \\
\hline 12. Nurses are politically active. & 1 & 5 & 2.53 & 0.89 & 1 & 5 & 2.96 & 0.89 & 4438.000 & $<0.001^{* *}$ \\
\hline $\begin{array}{l}\text { 13. Nurses are capable of independent } \\
\text { practice. }\end{array}$ & 1 & 5 & 3.91 & 0.94 & 1 & 5 & 4.39 & 0.76 & 4303.000 & $<0.001^{* *}$ \\
\hline $\begin{array}{l}\text { 14. Nurses speak out against inadequate } \\
\text { working conditions. }\end{array}$ & 1 & 5 & 3.23 & 0.97 & 1 & 5 & 2.86 & 1.13 & 4845.500 & $0.009^{* *}$ \\
\hline $\begin{array}{l}\text { 15. Nurses are not compensated sufficiently } \\
\text { for their work by the knowledge that } \\
\text { they are helping people. }\end{array}$ & 1 & 5 & 3.59 & 1.12 & 1 & 5 & 3.82 & 1.04 & 5311.000 & 0.107 \\
\hline
\end{tabular}


Table 1. Continued

\begin{tabular}{|c|c|c|c|c|c|c|c|c|c|c|}
\hline \multirow{2}{*}{ Item } & \multicolumn{4}{|c|}{ First year of study } & \multicolumn{4}{|c|}{ Third year of study } & \multicolumn{2}{|c|}{ Mann-Whitney U test } \\
\hline & Min & Max & $\mathrm{M}$ & $\mathrm{SD}$ & Min & Max & M & SD & Result & $\mathrm{p}$ \\
\hline 16. Nurses should have a right to strike. & 1 & 5 & 4.09 & 0.92 & 1 & 5 & 4.54 & 0.84 & 4225.500 & $<0.001^{* *}$ \\
\hline $\begin{array}{l}\text { 17. Nurses do not follow physicians' orders } \\
\text { without questions.* }\end{array}$ & 1 & 5 & 3.04 & 1.16 & 1 & 5 & 3.61 & 1.08 & 4416.000 & $<0.001^{* *}$ \\
\hline 18. Men make good nurses. & 1 & 5 & 4.10 & 0.82 & 1 & 5 & 4.45 & 0.72 & 4539.500 & $0.001^{* *}$ \\
\hline $\begin{array}{l}\text { 19. Many nurses who seek advanced } \\
\text { degrees in nursing would not really } \\
\text { rather be physicians.* }\end{array}$ & 1 & 5 & 2.98 & 1.03 & 1 & 5 & 3.49 & 0.96 & 4450.000 & $<0.001^{* *}$ \\
\hline 20. Nursing is exciting. & 1 & 5 & 4.18 & 0.77 & 3 & 5 & 4.36 & 0.69 & 5355.000 & 0.089 \\
\hline $\begin{array}{l}\text { 21. Nurses incorporate research findings } \\
\text { in their clinical practice. }\end{array}$ & 2 & 5 & 3.62 & 0.80 & 1 & 5 & 3.88 & 0.91 & 4988.000 & $0.013^{* *}$ \\
\hline $\begin{array}{l}\text { 22. The major goal of nursing research } \\
\text { is to improve patient care. }\end{array}$ & 2 & 5 & 4.17 & 0.74 & 2 & 5 & 4.38 & 0.72 & 5069.000 & $0.018^{* *}$ \\
\hline $\begin{array}{l}\text { 23. Nurses are not adequately paid } \\
\text { for the work they do.* }\end{array}$ & 1 & 5 & 3.71 & 0.96 & 2 & 5 & 4.29 & 0.78 & 4046.000 & $<0.001^{* *}$ \\
\hline $\begin{array}{l}\text { 24. Nurses value time at bedside caring } \\
\text { for patients. }\end{array}$ & 1 & 5 & 3.27 & 0.85 & 1 & 5 & 3.41 & 0.88 & 5584.000 & 0.245 \\
\hline $\begin{array}{l}\text { 25. Nurses should have a baccalaureate } \\
\text { degree for entrance into practice. }\end{array}$ & 1 & 5 & 3.63 & 1.10 & 1 & 5 & 3.80 & 1.07 & 5532.500 & 0.218 \\
\hline $\begin{array}{l}\text { 26. Nurses with completed undergraduate } \\
\text { nursing studies and graduate studies } \\
\text { significantly contribute to patient care. }\end{array}$ & 1 & 5 & 4.32 & 0.80 & 1 & 5 & 4.29 & 0.79 & 5938.000 & 0.717 \\
\hline $\begin{array}{l}\text { 27. One advantage of being a nurse } \\
\text { is not to marry a physician.* }\end{array}$ & 1 & 5 & 3.78 & 1.43 & 1 & 5 & 4.61 & 0.80 & 4078.500 & $<0.001^{* *}$ \\
\hline 28. Nursing is a respected profession. & 1 & 5 & 3.45 & 1.14 & 1 & 5 & 2.68 & 1.11 & 3843.000 & $<0.001^{* *}$ \\
\hline $\begin{array}{l}\text { 29. Nurses consistently update their } \\
\text { practices in relation to current health } \\
\text { trends. }\end{array}$ & 1 & 5 & 3.52 & 0.99 & 1 & 5 & 3.21 & 1.10 & 5174.000 & $0.043^{* *}$ \\
\hline 30. Nurses feel good about what they do. & 1 & 5 & 3.34 & 0.85 & 1 & 5 & 3.02 & 1.00 & 5031.000 & $0.017^{\text {** }}$ \\
\hline
\end{tabular}

*recorded; ${ }^{* *} \mathrm{p}<0.05$

$\mathrm{M}=2.57$ to $\mathrm{M}=4.74$ for third-year results. The lowest arithmetic mean at both measurement points was recorded in item 4 (Nurses should not wear the blue uniform in order to be recognized): first year $\mathrm{M}=2.34$, $\mathrm{SD}=1.09$ and third year $\mathrm{M}=2.57, \mathrm{SD}=1.26$. In the first year of the study, the highest arithmetic mean of $\mathrm{M}=4.5, \mathrm{SD}=0.65$ was recorded in item 5 (Nurses act as resource persons for individuals with health problems), and in the third year of the study $(\mathrm{M}=4.74, \mathrm{SD}=0.54)$ in item 8 (The service given by nurses is as important as that given by physicians).

In first-year students, the highest standard deviation ( $\mathrm{SD}=1.43$ ) was found in item 27 (One advantage to being a nurse is not to marry a physician) and lowest standard deviation $(\mathrm{SD}=0.65)$ in item 10 (Nurses integrate health teaching into their practice). In third-year students, highest standard deviation $(\mathrm{SD}=1.26)$ was recorded in item 4 (Nurses should not wear the blue uniform in order to be recognized) and lowest standard deviation $(\mathrm{SD}=0.51$ ) in item 5 (Nurses act as resource persons for individuals with health problems).

The results of Kolmogorov-Smirnov test showed significant deviation from normal distribution in both measurements.

In the period from the first to third year of the study, there was a statistically significant change of attitudes in 21 items. Of these, the average score was recorded in 17 items. Students of the third year had a 
stronger attitude related to the importance of nurses when caring for the patient, firmly stating that nurses are advocates of patient rights, protect the patient in the health care system, and that the interventions provided by nurses are as important as the interventions provided by physicians. A positive attitude related to the research and application of research in the work of nurses was significantly expressed in the third year of the study. At the end of their study, students were convinced that nurses were kind and compassionate persons, that intelligence was needed to be a nurse, and that men were good nurses. At the end of the study, students also strongly expressed a view that nurses were not expected to follow physician's instructions without question, that in their daily work nurses included health education, and that they were politically active and qualified to work independently. Third-year students were more convinced that many nurses that want to advance in nursing would not prefer be physicians, that nurses should have the right to strike, and that one of the advantages of being a nurse was not the possibility of marrying a physician. Third-year students strongly expressed a view that nurses were not adequately paid for their job.

In 4 items showing significant changes over time, the estimates of examinees were found to have decreased. At the end of the study, students less frequently expressed the view that nurses talk openly about inadequate working conditions, that nurses feel good about the work they do, that nurses constantly improve their practices in line with trends in health care, and that nursing is a respected profession.

In the other nine questionnaire items there was no statistically significant difference. At the beginning and at the end of the study, students believed that nurses offered support to people with health problems, participated in the development of health policies, did not find compensation for their work only in helping other people, that nursing was exciting, and that nurses appreciated time spent at patient bedside by providing care for patients. At the beginning and at the end of the study, they strongly expressed the view that to enter the nursing profession it was necessary to complete the study, and that nurses with completed studies of nursing and specialist graduate studies contributed significantly to patient care. Students believe that nurses should wear blue uniform to make them recognizable. Students had a relatively neutral opinion re- garding the item that everyone would benefit more if nurses would spend less time in school, while spending more time to care for patients.

\section{Discussion}

In this study conducted among nursing students, changes were found in 21 of 30 items of the Nursing Image Questionnaire. There was positive change in the attitudes in the majority ( $n=17)$ of items, and at the end of the study they expressed lower attitude in only four items. In the other nine items, there was no statistically significant difference between the two measurements.

At the beginning of the study, many students had idealistic perception of nursing, and the perception changed under the influence of educational program due to the influence of nursing theory and science, and clinical experience ${ }^{17,18}$. It is expected that during their study program, students acquire the necessary competence for independent, safe and quality nursing care, and that they develop professional identity.

Unlike Toth $e t a l{ }^{15}$, who conclude that the attitude of students is stable during the study, most researchers state that attitudes toward nursing were changing under the influence of educational program ${ }^{18,19}$. The results of this study are similar to the results obtained in the studies conducted by Bolan and Grainger ${ }^{20}$ and Grainger and Bolan ${ }^{21}$. In these studies, students of the final year had a pronounced opinion that nurses were advocates of patient rights, that they protected the patient in the health care system, and that the interventions provided by nurses were as important as the interventions provided by physicians. At the end of the study, students in both studies expressed positive attitudes related to the research and application of research in the work of nurses.

In a study conducted in 2011, students of final year of nursing study in Croatia indicated that research was relevant for the development of the nursing profession, which was confirmed by the present study. Although the attitude that nursing is an esteemed profession, in this study it was lower at the end of the study than at the beginning of the study and it differed from the previous study, where the majority of final year students of nursing (63\%) stated that nursing was not appreciated $^{22}$. In contrast but in accordance with the results of this research, in a study conducted in the gen- 
eral population on a Croatian island, researchers concluded that nursing was an esteemed profession in the society $^{23}$.

Final year students of nursing in Belgium believe that nursing is a low-paid profession ${ }^{24}$, and similar results were obtained in this study. Although it is believed that nursing is underpaid, stating that helping others is not enough compensation, students are studying and completing their studies, which can speak in favor of their high motivation for nursing and development of professional identity.

Development of professional identity is evident in the results, where final year students had the strongest position on the item that the intervention provided by nurses is as important as the interventions provided by physicians.

Students strongly express the views related to the importance of higher education of nurses, which can also be linked to their motivation for studying and their determination to complete the study.

Acquiring knowledge significantly affects the nursing students' perception of nursing ${ }^{25}$, and the perception of nursing is created during the study based on the observations in real terms during clinical training ${ }^{26}$. This can be seen in the results of this study, where at the end students less frequently expressed the view that nurses felt good about the work they did and that they continually improved their practices in line with trends in health care. The students with an unrealistic picture of the profession tended to give up their continuing and completing the study ${ }^{27}$. During student education, theoretical and practical training, it is necessary to pay due attention to the adoption of specific nursing knowledge, so that students can adopt positive professional identity and work as nurses after graduation.

The main limitation of the present study was the fact that it was conducted at a single institution of higher education, University of Applied Health Sciences, for which there is greatest interest for enrolment of candidates in Croatia; in addition, some results may be related to the fact that the students were highly motivated to acquire knowledge and skills of nursing practice. Therefore, research should be carried out on more nursing studies to enable comparison of the results obtained. Additional studies may be focused on detection of factors that influence the alteration of attitudes of nursing students and assessing the influence of educational contents on changing student attitudes.

\section{Conclusion}

This study conducted in nursing students indicated that students' attitudes changed during undergraduate study, influenced by the acquisition of knowledge and skills. During the study, students acquire a more realistic picture of nursing, and it comes to the adoption of professional values. The role of nurses' educators is particularly evident because they have an important role in the development of professional identity and can influence reduction of dropouts. Equally important is the perception of the nursing profession in the public because part of the students are coming with the idealistic perception of nursing, which can also contribute to withdrawal from the study program.

\section{References}

1. Dante A, Valoppi G, Saiani L, Palese A. Factors associated with nursing students' academic success or failure: a retrospective Italian multicenter study. Nurs Educ Today. 2011;31: 59-64. http://dx.doi.org/10.1016/j.nedt.2010.03.016

2. Urwin S, Stanley R, Jones M, Gallagher A, Wainwright P, Perkins A. Understanding student nurse attrition: learning from the literature. Nurs Educ Today. 2010;30:202-7. http:// dx.doi.org/10.1016/j.nedt.2009.07.014

3. Mulholland J, Anionwu EN, Atkins R, Tappern M, Franks JP. Diversity, attrition and transition into nursing. J Adv Nurs. 2008;64(1):45-59. http://dx.doi.org/10.1111/j.1365$-2648.2008 .04758 . x$

4. Hemsley-Brown J, Foskett NH. Career desirability: young people's perception of nursing as a career. J Adv Nurs. 1990;29(6):1342-50. http://dx.doi.org/10.1046/j.1365-2648. 1999.01020.x

5. Boughn S, Lentini A. Why do women choose nursing? J Nurs Educ. 1999;38(4):156-61. http://dx.doi.org/10.3928/01484834-19990401-05

6. Dal U, Arifoglu BC, Razi GS. What factors influence students in their choice of nursing in North Cyprus? Procedia Soc Behav Sci. 2009;1:1924-30. http://dx.doi.org/10.1016/j.sbspro. 2009.01.338

7. Mooney M, Glacken M, O'Brien F. Choosing nursing as a career: a qualitative study. Nurs Educ Today. 2008;28:385-92. http://dx.doi.org/10.1016/j.nedt.2007.07.006

8. Boughn S. Why women and men choose nursing. Nurs Health Care Perspect. 2001;22(1):14-9.

9. Price SL. Becoming a nurse: a meta study of early professional socialization and career choice in nursing. J Adv Nurs. 2009;65(1):11-9. http://dx.doi.org/10.1111/j.1365-2648.2008. 04839.x

10. Larsen PD, McGill JS, Palmer SJ. Factors influencing career decisions: perspectives of nursing students in three types of 
programs. J Nurs Educ. 2003;42(4):168-73. http://dx.doi. org/10.3928/0148-4834-20030401-07

11. Buerhaus P, Donelan K, Norman L, Dittus R. Nursing students' perceptions of a career in nursing and impact of a national campaign designed to attract people into the nursing profession. J Prof Nurs. 2005;21(2):75-83. http://dx.doi. org/10.1016/j.profnurs.2005.02.001

12. Kersten J, Bakewell K, Meyer D. Motivating factors in a student's choice of nursing as a career. J Nurs Educ. 1991;30(1): 30-3. http://dx.doi.org/10.3928/0148-4834-19910101-08

13. Day RA, Field PA, Campbell IE, Reutter L. Student's evolving beliefs about nursing: from entry to graduation in a four year baccalaureate programme. Nurs Educ Today. 2005;25:636-43. http://dx.doi.org/10.1016/j.nedt.2005.09.003

14. Watson R, Deary IJ, Lea A. A longitudinal study into the perceptions of caring and nursing among student nurses. J Adv Nurs. 1999;29(5):1228-37. http://dx.doi.org/10.1046/j.13652648.1999.01008.x

15. Toth JC, Dobratz MA, Boni MS. Attitude toward nursing of students earning a second degree and traditional baccalaureate students: Are they different? Nurs Outlook. 1998,46(6):273-8. http://dx.doi.org/10.1016/S0029-6554(98)90083-5

16. Beaton D, Bombardier C, Guillemin F, Bosi Ferraz M. Guidelines for the process of cross-cultural adaptation of self-report measures. Spine. 2000;25(24):3186-91.

17. Brodie DA, Andrews GJ, Andrews JP, Thomas GB, Wong J, Rixon L. Perceptions of nursing confirmation, change and the student experience. Int J Nurs Stud. 2004;41:721-33. http:// dx.doi.org/10.1016/j.ijnurstu.2004.02.009

18. Safadi RR, Saleh MYN, Nassar OS, Amre HM, Froelicher ES. Nursing students' perceptions of nursing: a descriptive study of four cohorts. Int Nurs Rev. 2011;58(4):420-7. http://dx.doi. org/10.1111/j.1466-7657.2011.00897.x

19. Sand-Jecklin K, Schaffer A. Nursing students' perceptions of their chosen profession. Nurs Educ Perspect. 2006;27(3):130-5.
20. Bolan C, Grainger P. Students in the BN program - do their perceptions change? Nurs Educ Today. 2009;29:775-9. http:// dx.doi.org/10.1016/j.nedt.2009.03.016

21. Grainger P, Bolan C. Perceptions of nursing as a career choice of students in the baccalaureate nursing program. Nurs Educ Today. 2006;26:38-44. http://dx.doi.org/10.1016/j.nedt.2005. 06.004

22. Čukljek S, Karačić J, Ilić B. Attitudes of $3^{\text {rd }}$ year nursing students about nursing in Croatia today. In: Pavić J, Turuk V, editors. Croatian nursing toward European Union. Book of conference papers of the $11^{\text {th }}$ Nursing Conference Croatian Nursing toward European Union, 2011 Mar 24-26; Opatija, Croatia. Zagreb: University of Applied Health Sciences, 2011. p. 169-76. (in Croatian)

23. Gavranić D, Iveta V, Sindik J. Perception of the nurse profession in general public. Sestrinski glasnik. 2015;20:115-20. (in Croatian) http://dx.doi.org/10.11608/sgnj.2015.20.025

24. Milisen K, De Busser T, Kayaert A, Abraham I, de Casterle $B D$. The evolving professional nursing self-image of students in baccalaureate programs: a cross-sectional survey. Int J Nurs Stud. 2010;47(6):688-98. http://dx.doi.org/10.1016/j.ijnurstu. 2009.11.008

25. Karaoz S. Change in nursing students' perceptions of nursing during their education: the role of the Introduction to Nursing course in this change. Nurs Educ Today. 2004;24:128-35. http://dx.doi.org/10.1016/j.nedt.2003.10.010

26. Manninen E. Changes in nursing students' perceptions of nursing as they progress through their education. J Adv Nurs. 1998;27:390-8. http://dx.doi.org/10.1046/j.1365-2648.1998. 00521.x

27. Cowin LS, Johnson M. Many paths lead to nursing: factors influencing students' perceptions of nursing. Int Nurs Rev. 2011;58:413-9. http://dx.doi.org/10.1111/j.1466-7657.2011. 00905.x 


\title{
Sažetak \\ PROMJENE TIJEKOM STUDIJA U STAVOVIMA STUDENATA SESTRINSTVA PREMA SESTRINSTVU
}

\author{
S. Čukljek, V. Jureša, C. Grgas Bile i B. Režek
}

Cilj istraživanja bio je utvrditi stavove studenata na studiju sestrinstva prema sestrinstvu te promjene njihovih stavova tijekom studija. Provedeno je kvantitativno istraživanje s ispitivanjem prije i poslije studija među studentima na redovnom studiju sestrinstva koji su akademske godine 2012./2013. upisali prvu godinu studija ( $\mathrm{N}=115)$, a u akademskoj godini 2014./2015. treću godine studija ( $N=106)$. Studenti su dobrovoljno i anonimno ispunili upitnik koji obuhvaća demografske podatke i Upitnik stavova o sestrinstvu (Nursing Image Questionnaire). Upitnik stavova o sestrinstvu obuhvaća 30 čestica koje mjere kako pojedinac gleda na uloge i zadaće medicinskih sestara, vrijednosti, društvene stereotipe prema sestrinstvu, profesionalizam i karakteristike sestara/sestrinstva. Rezultati ukazuju na to da studenti na početku i tijekom studija imaju pozitivan stav prema sestrinstvu. Tijekom studija došlo je do pozitivne promjene stavova u većini čestica upitnika, dok je u samo 4 čestice na kraju studija izražen niži stav. Istraživanje provedeno među studentima na studiju sestrinstva ukazuje na to da se stavovi studenata mijenjaju tijekom prvostupničkog studija pod utjecajem usvajanja znanja i vještina. Tijekom studija studenti usvajaju realističniju sliku sestrinstva te dolazi do usvajanja profesionalnih vrijednosti.

Ključne riječi: Sestrinstvo, izobrazba; Prvostupnički studij; Percepcije; Stavovi 